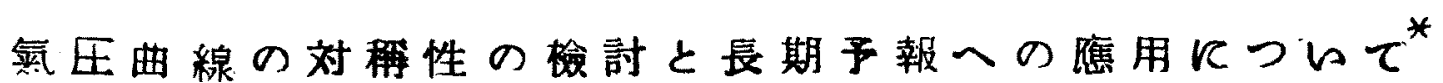
矢 讯 二**

\title{
\$1序言
}

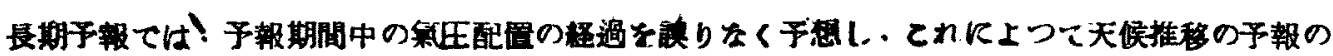

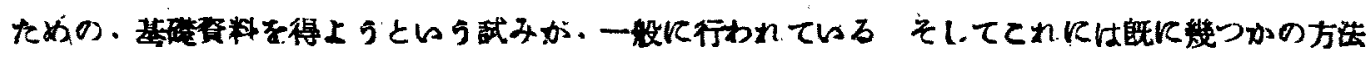

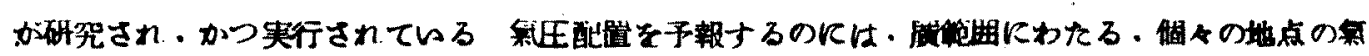

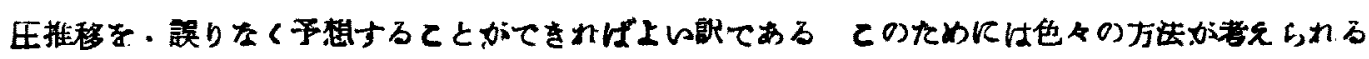

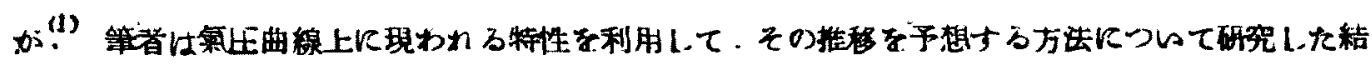

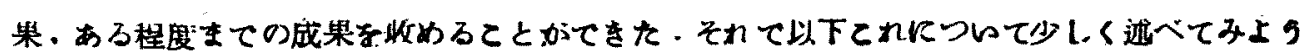

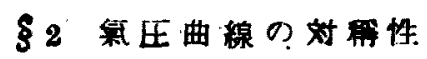

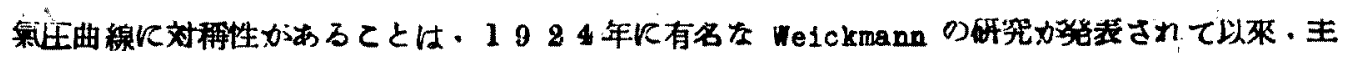
とし、て Leipzig 学派の人やに上つてさかんに啸されて、既に多くの報文加明らかにされている.

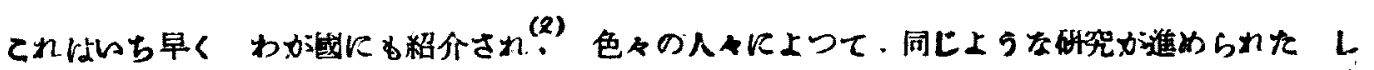

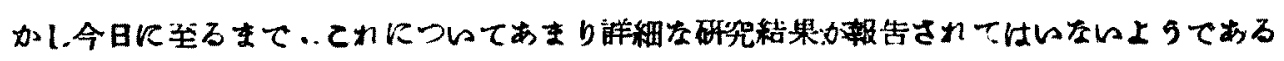

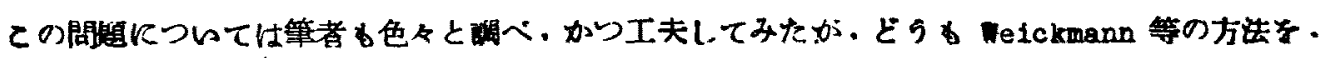

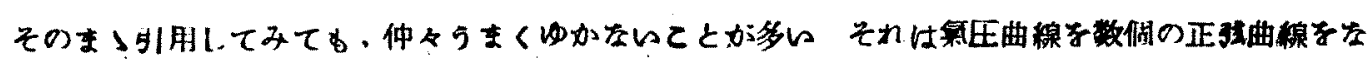

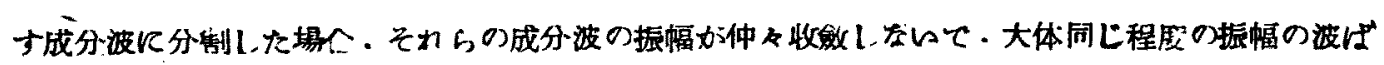

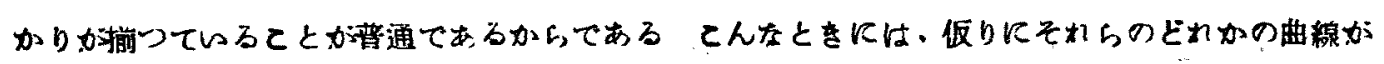

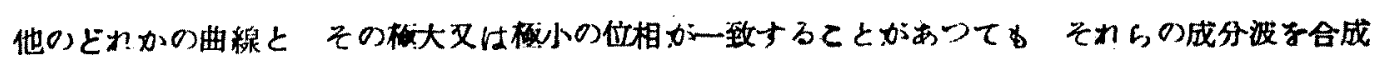
し、たとてろて、原曲線とは仲々近い曲線とはならをいから，結局のとてろ折䚙見した対稱点。

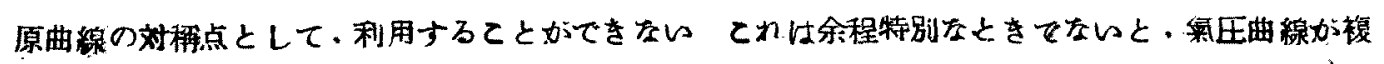

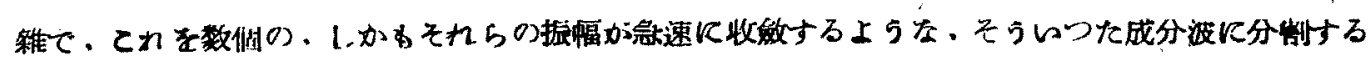

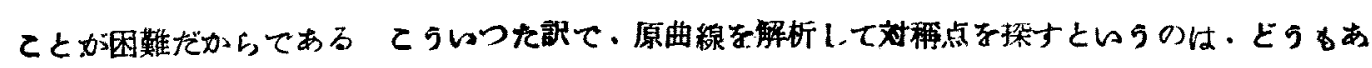

* Y. Yazawa: Study of the Symmetry Characters Pound on the Pressure Curve and lpplication of its results to Long-Rang Forecesting.

**中央柏策

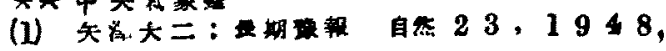

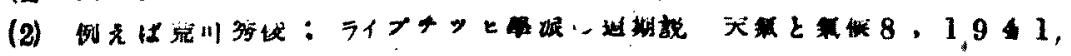


まりらまくいかをいととか分つた。

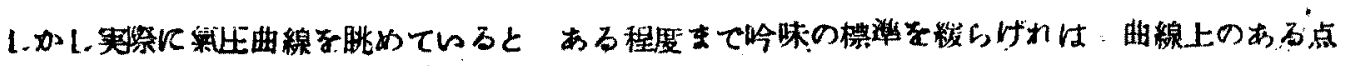

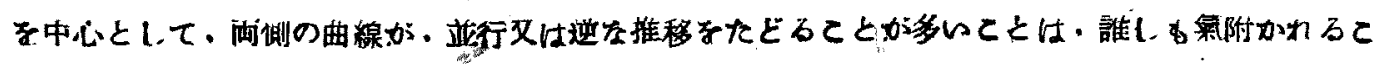

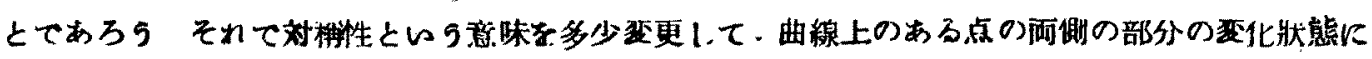

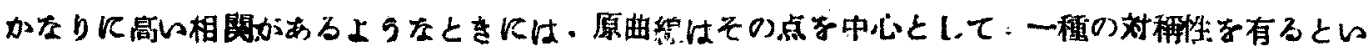

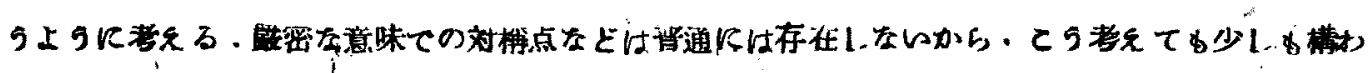

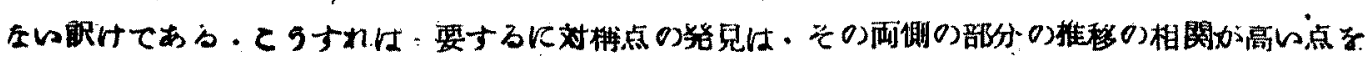

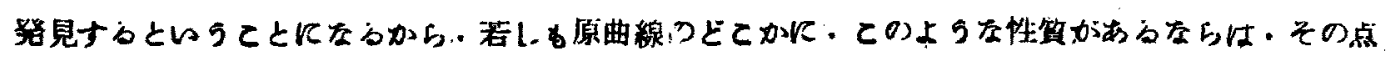

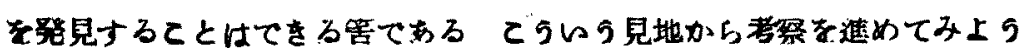

\section{\$8 稱点の探荣}

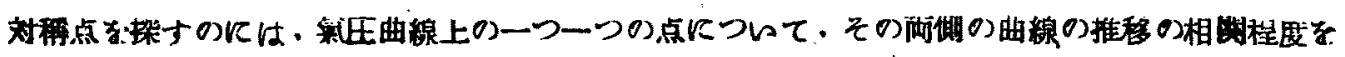

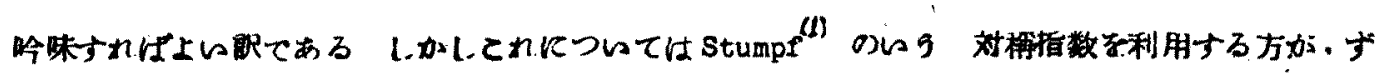

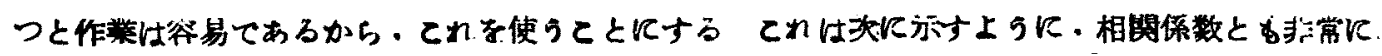

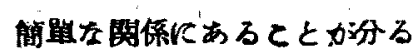

今

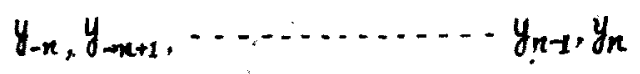

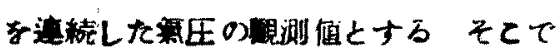

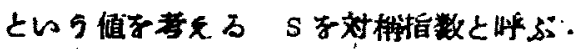

$$
S=\frac{\sum\left(y_{\nu}-y_{-\nu}\right)^{2}}{\sum\left(y_{\nu}-y_{-\nu}\right)^{2}+\sum\left(y_{\nu}+y_{-\nu}\right)^{2}}
$$

対样指数 Sはをた

$$
S=\frac{2 \Sigma y_{\nu}^{2}-2 \Sigma y_{\nu} y_{-\nu}}{4 \sum y_{\nu}^{2}}=\frac{1}{2}(1-k)
$$

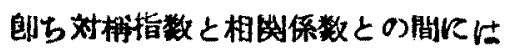

$$
k=1-2 S
$$

の條がある・それて

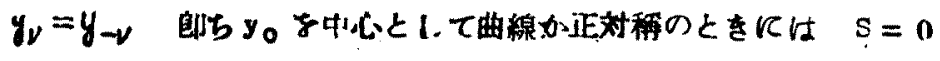

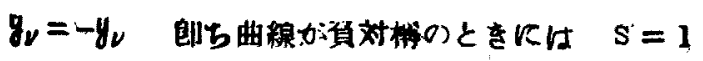

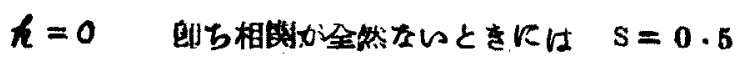

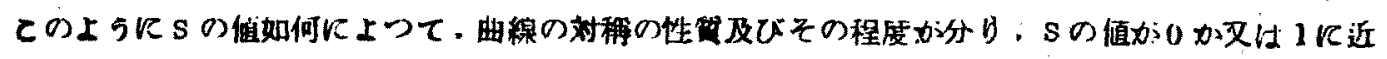

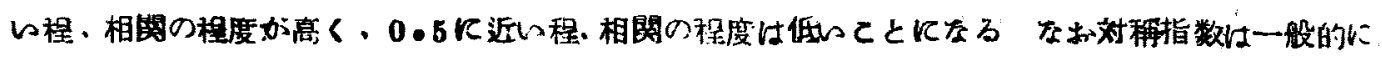
lis

$$
S=\frac{\sum\left(y_{\nu}-y_{-\nu}\right)^{2}}{\sum\left(y_{\nu}-y_{-\nu}\right)^{2}+\sum\left(y_{\nu}+y_{-\nu}\right)^{2}-\frac{1}{n} \sum\left(y_{\nu}+y_{-\nu}\right)^{2}} \quad \cdots \cdots-\nu_{4}
$$

(1) Stump: Grundlagẹn u. Methoden d. Periodenforscidung. 1937. ven. 1938.

" Unterguchurgen über die Symetrie-Ejgers sherien von Luftdruckkur. 
で表わされるから・とれを主に使らこととする。

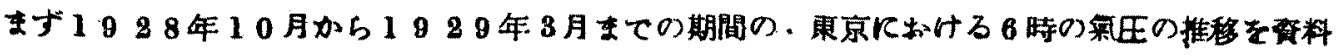

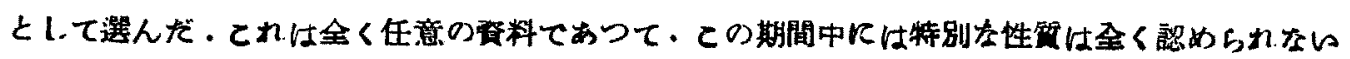

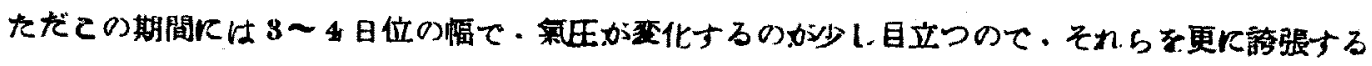

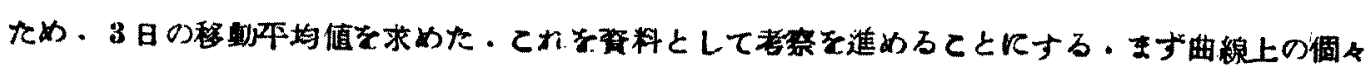

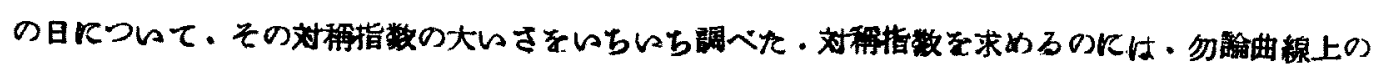

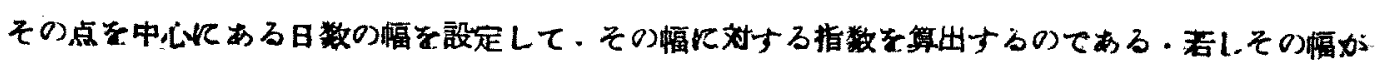

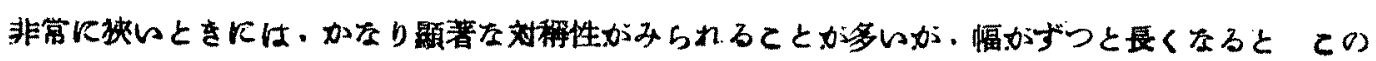
性算は段々と不明东になる

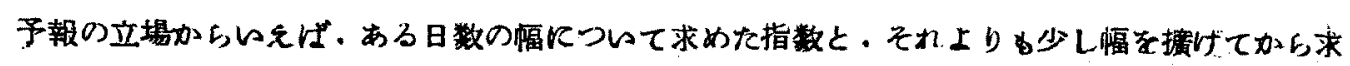

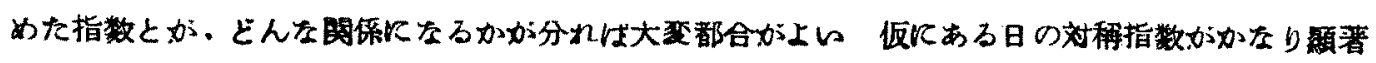

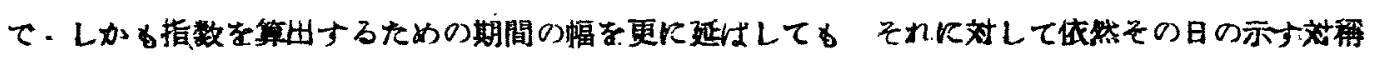

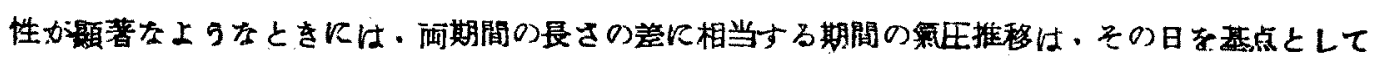

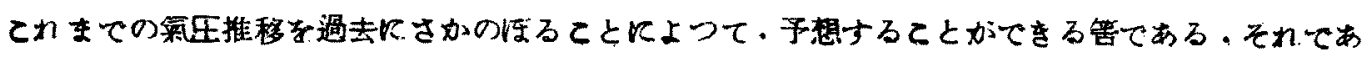

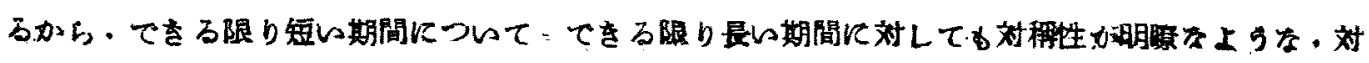

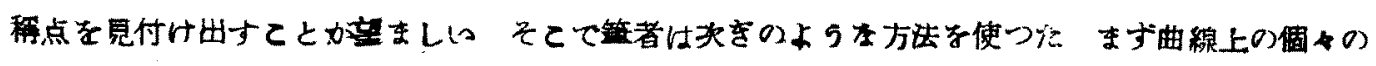

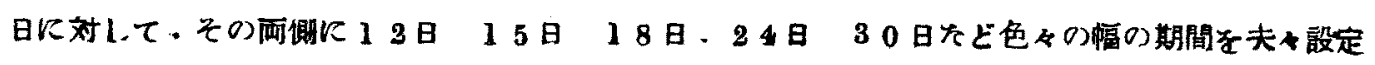

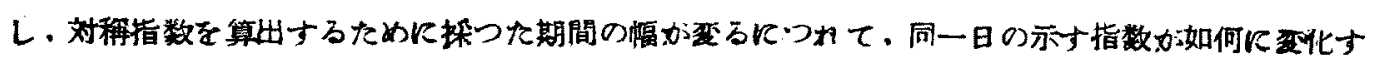
るかる調へた。その結果を次に示したけ第】表蜰い

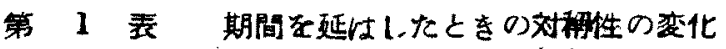

\begin{tabular}{|c|c|c|c|c|c|c|}
\hline & $a \quad b$ & a & $a$ & a & a & 2 \\
\hline 調べた期閻の幅 & 1218 & $18 \quad 24$ & $24 \quad 30$ & $15 \quad 24$ & $18 \quad 30$ & $12 \quad 24$ \\
\hline 期間の美 & \multicolumn{3}{|c|}{6} & & \multicolumn{2}{|c|}{12} \\
\hline (1) & $16 \quad 13$ & 4 & 2 & 88 & 4 & 140 \\
\hline (2) & $\begin{array}{ll}38 & 22\end{array}$ & $17 \quad 13$ & 11 & $20 \quad 12$ & 16 & $34 \quad 15$ \\
\hline (2) & 6133 & $28 \quad 2.1$ & $26 \quad 19$ & $37 \quad 20$ & $27 \quad 12$ & $\begin{array}{ll}55 & 24\end{array}$ \\
\hline 調查日数 & 146 & 134 & 120 & 134 & 120 & 134 \\
\hline
\end{tabular}

㿟ら初か闻挪 に12日ナ゙つの 幅を設定して算 出し，た称指数 が 0.9 タくは。. arつvr 仕
(1) $s>0$

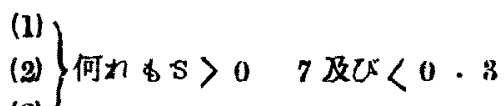
(2) $s>0 \quad 8:<\begin{array}{lll}0 & 2\end{array}$
(a) $s>0 \cdot 75$ 及じく0 25

1)の点のち

檑を更化 18 日 て延ばしたとを Ko $0.7<$ 壮

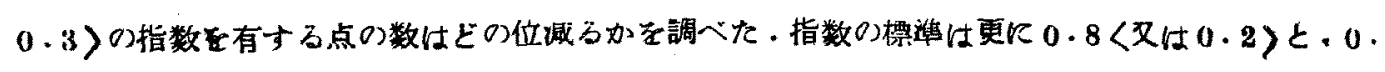

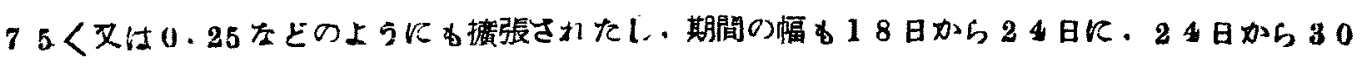

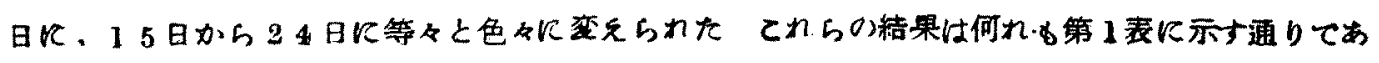


るこれからみると 12 日の幅て0 0 くくか 1〉の指数を有する点は 期間を6 日間延はし

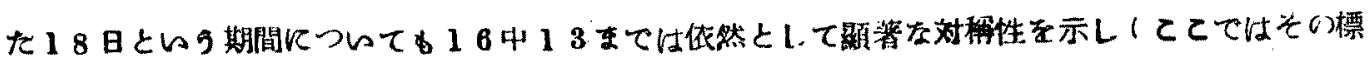

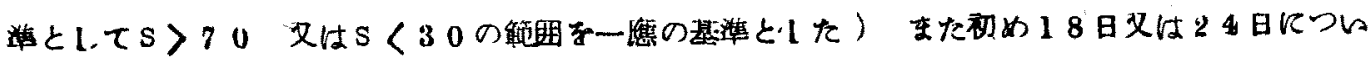

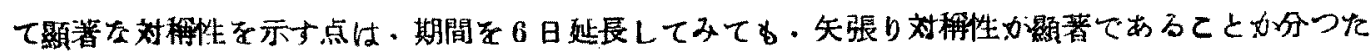

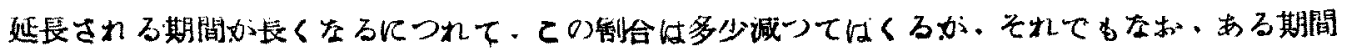

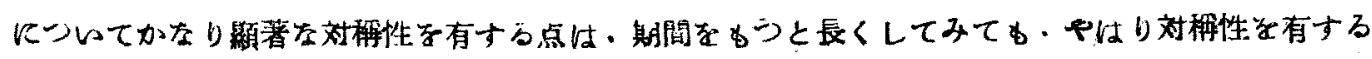

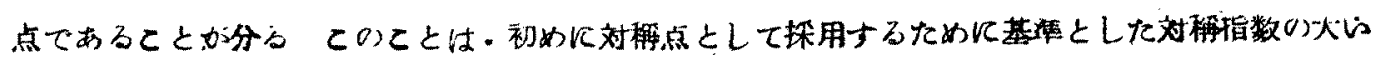

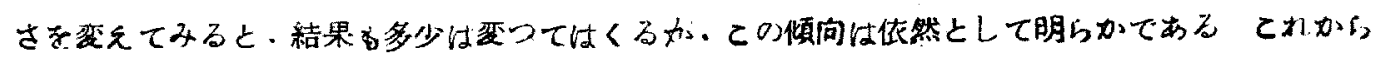
いわれるととは、い主探用している资料では、初めに十数日又は二十数日といら期間に対して・相

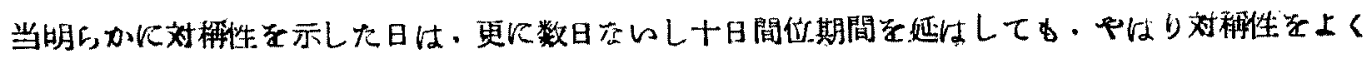

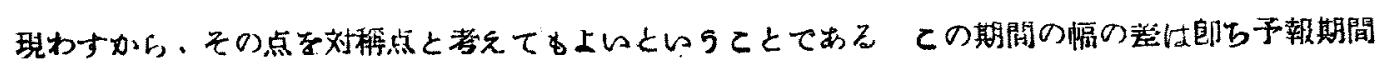

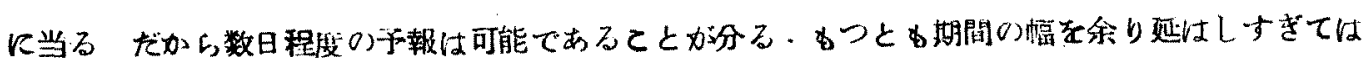

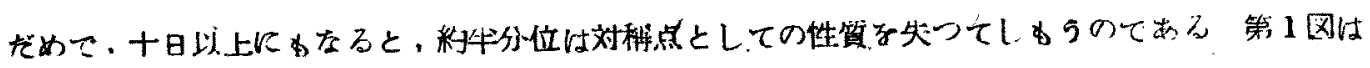

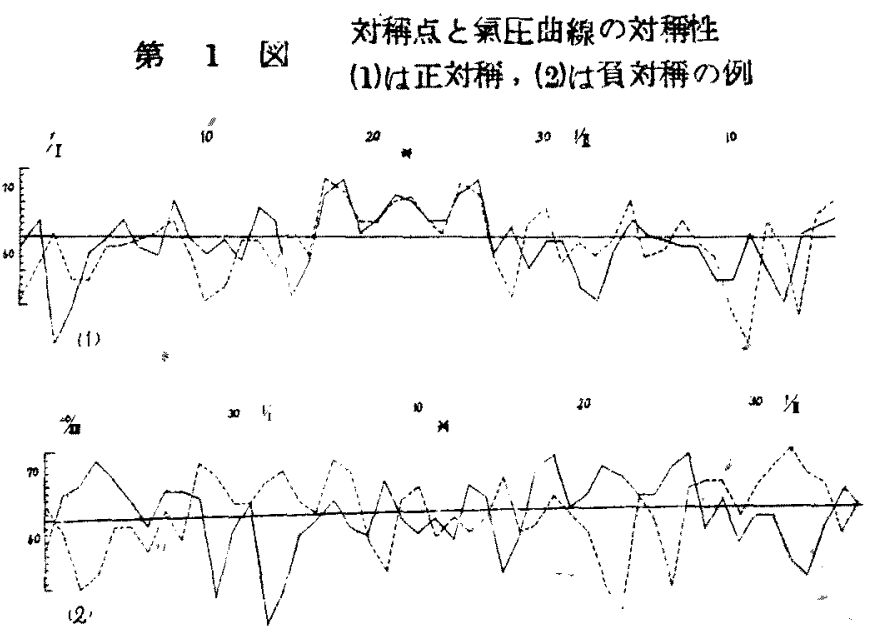

東宗のての期闍の氣正曲線であるが 图に示した星印的刘诨点て, 点線は ての点子中心として, 原明線学反轉 させためのであるるスと例とし

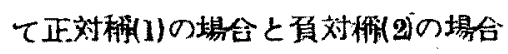
とを示したが，(1)では再曲線加か左

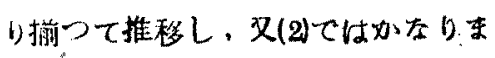
て互い羊に提移していること份 3

以上は前に示した資料につルて得

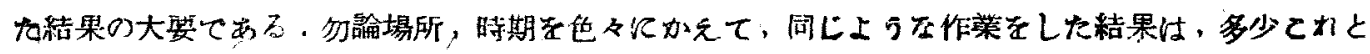

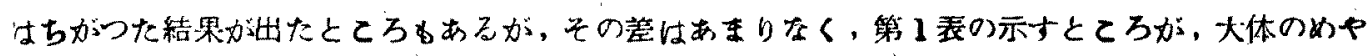
ナと各るとみエい上らてある

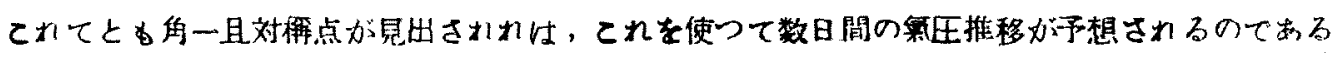

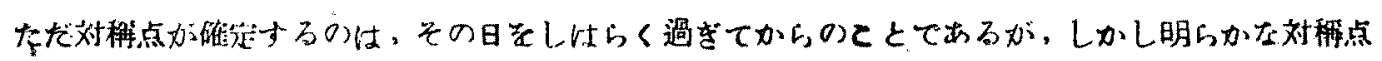

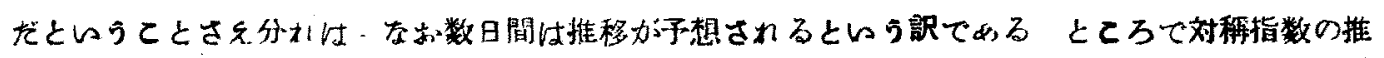

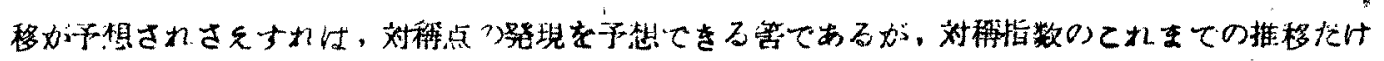

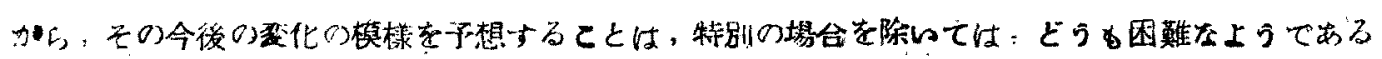


第 8 図には、色々の幅を設定

して求めた対稱指数の推移の

一例交してある

§4 対䄼性を舞期甬 報飞利用する万 法。
第 2 间

対䊈指数の推移（指数を求め

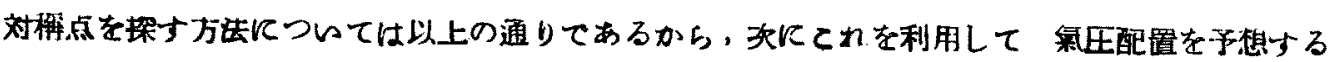

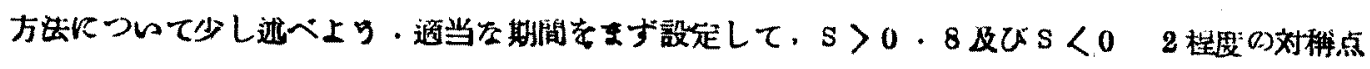

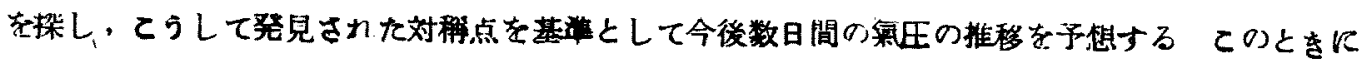
一つ拄意する必要がある それは対稱性というのは, 前にす边べたように, 要するに相閣関係の明

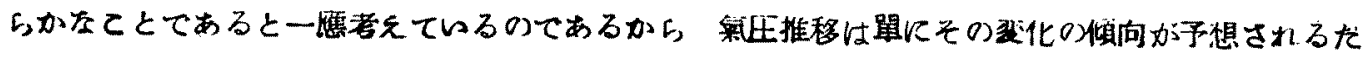

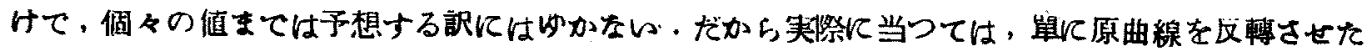
だけては必ずしす上い結果は得らっない。

この弊をさけるのには：予想檤に修正を加えることが望ましい これは色々に考えられるが、今

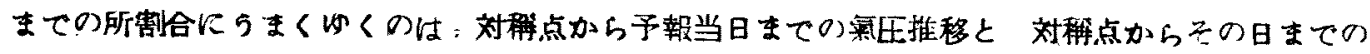

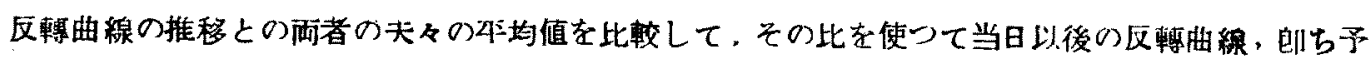

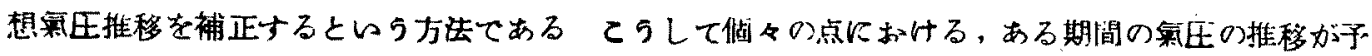

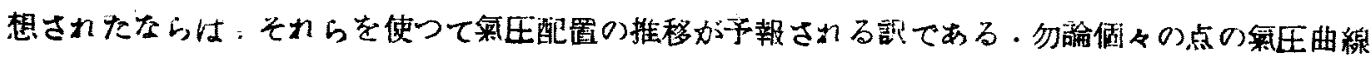

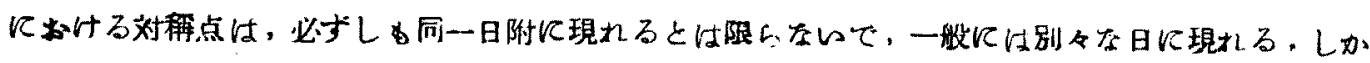
しこれは少しすし支えない。

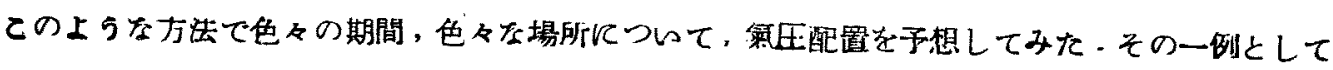

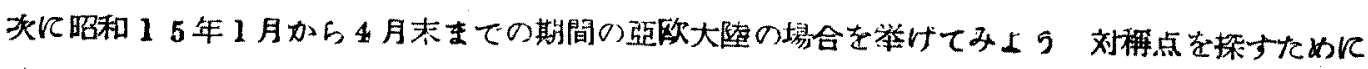

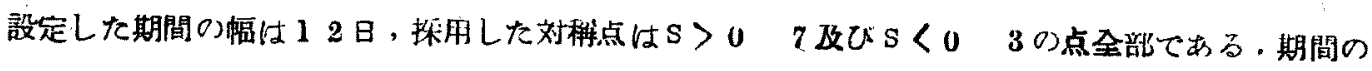

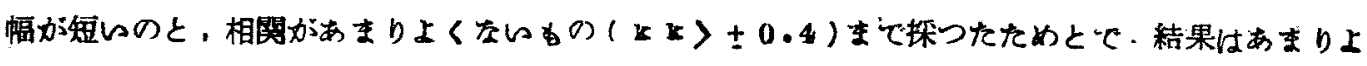

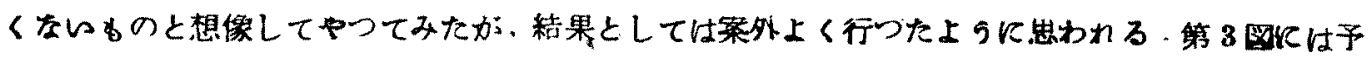

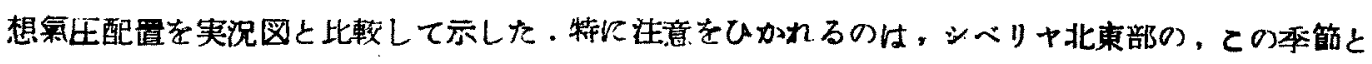

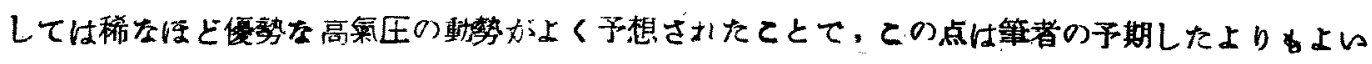

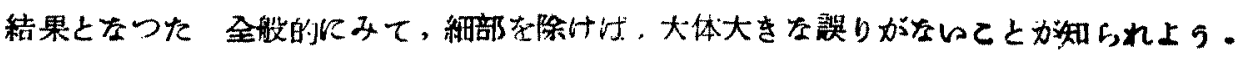

\section{$\$ 5$ 結語}

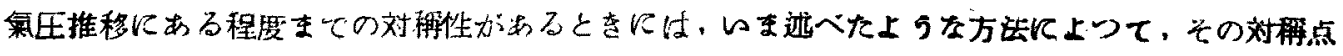

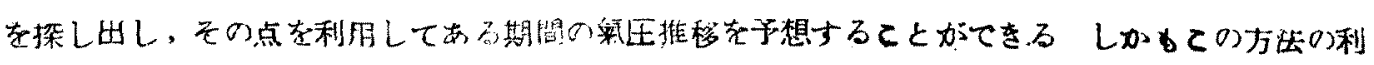




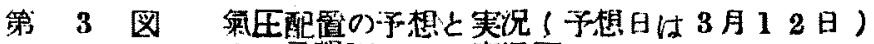

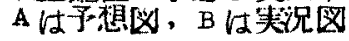

(1)

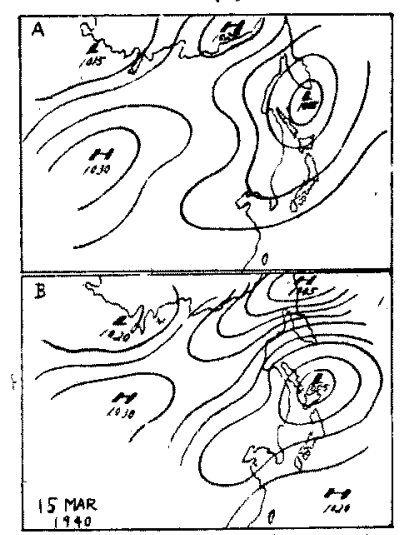

(2)

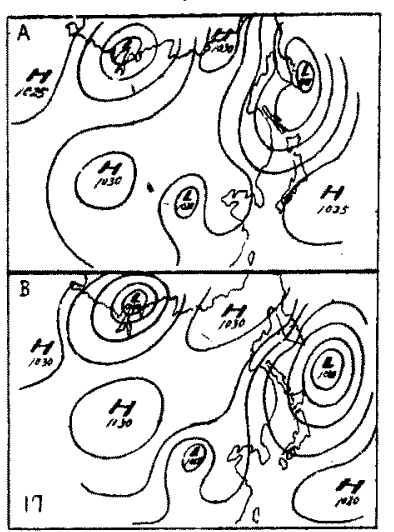

(3)

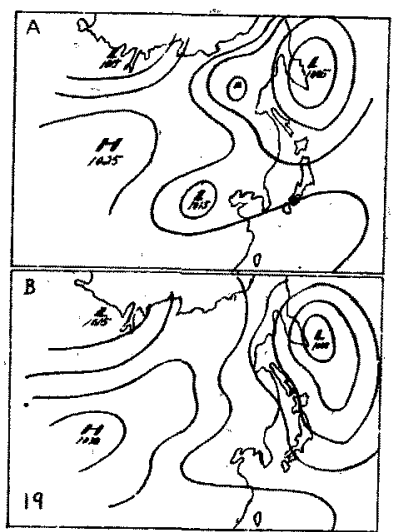

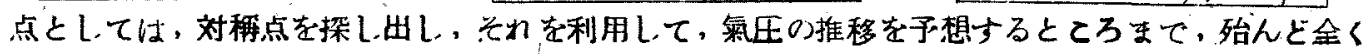

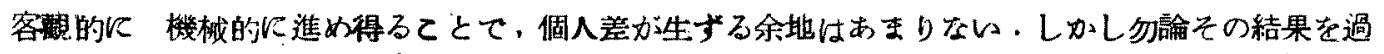

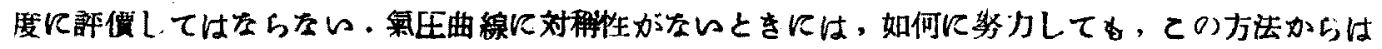
何を得らクないのてある。この辺を上く理解し、無理な結果を出そらとしないならば:この方法は 長期予報法の一一として，採用されてょいでろらなお今後に残されている閣題は－如何にして 対稱点を早期に見出すかといらてとて、筆者わ主としてての方面に今㣪研究を進めて心を度いと考 えている

この研究は日本学衡振興会の援助によつて行つている長期子報の呼究の一部てある ことに同会 に対して朢謝の意を表する。

䚄流境界展の場合の有限水槽上りの荥発一補遺 萩原 晣

\section{\$1 緒言}

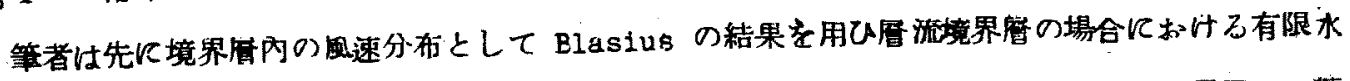

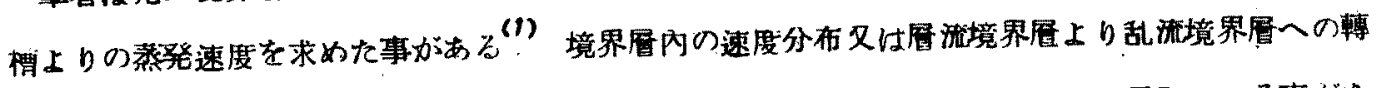

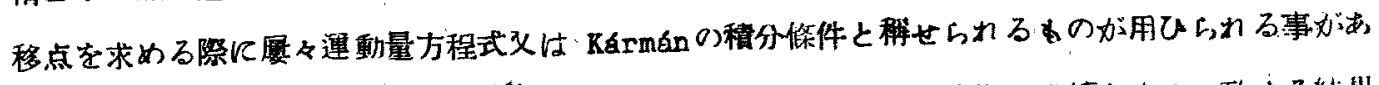

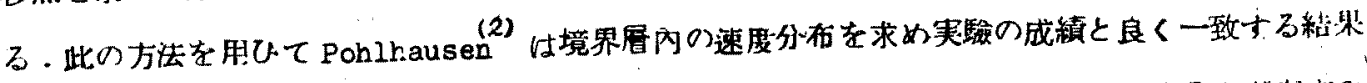

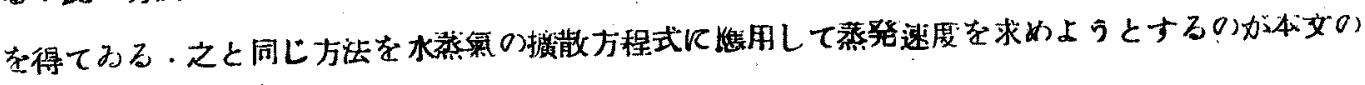
目的てむる

* S. Ogiwara: On the Evaporation of Water Irom a Vessel of Finite Dimensions in the Case of Laminar Boundary Layer - Supplementary Report.

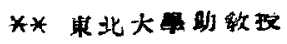

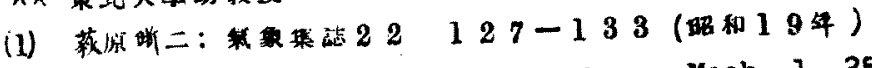

(2) Pohlhausen, ZS. 1. angew. Math. u. Mech. 1, 252 (1921). 